\title{
Paul's community formation in 1 Thessalonians: The creation of symbolic boundaries
}

\begin{tabular}{|c|c|}
\hline \multicolumn{2}{|c|}{$\begin{array}{l}\text { Authors: } \\
\text { Kwanghyun } \mathrm{Cho}^{1} \\
\text { Ernest van Eck }{ }^{2} \\
\text { Cas Wepener }\end{array}$} \\
\hline \multicolumn{2}{|c|}{$\begin{array}{l}\text { Affiliations: } \\
{ }^{1} \text { Department of Practical } \\
\text { Theology, Faculty of } \\
\text { Theology, University of } \\
\text { Pretoria, South Africa }\end{array}$} \\
\hline \multicolumn{2}{|c|}{$\begin{array}{l}{ }^{2} \text { Department of New } \\
\text { Testament Studies, Faculty } \\
\text { of Theology, University of } \\
\text { Pretoria, South Africa }\end{array}$} \\
\hline \multicolumn{2}{|c|}{$\begin{array}{l}\text { Correspondence to: } \\
\text { Cas Wepener }\end{array}$} \\
\hline \multicolumn{2}{|c|}{$\begin{array}{l}\text { Email: } \\
\text { cas.wepener@up.ac.za }\end{array}$} \\
\hline \multicolumn{2}{|c|}{$\begin{array}{l}\text { Postal address: } \\
\text { Private Bag X20, Hatfield } \\
\text { 0028, South Africa }\end{array}$} \\
\hline \multicolumn{2}{|c|}{$\begin{array}{l}\text { Dates: } \\
\text { Received: } 07 \text { Aug. } 2014 \\
\text { Accepted: } 16 \text { Jan. } 2015 \\
\text { Published: } 04 \text { June } 2015\end{array}$} \\
\hline \multicolumn{2}{|c|}{$\begin{array}{l}\text { How to cite this article: } \\
\text { Cho, K., Van Eck, E. \& Wepener, } \\
\text { C., 2015, 'Paul's community } \\
\text { formation in } 1 \text { Thessalonians: } \\
\text { The creation of symbolic } \\
\text { boundaries', HTS Teologiese } \\
\text { Studies/Theological Studies } \\
71(1), \text { Art. \#2804, } 7 \text { pages. } \\
\text { http://dx.doi.org/10.4102/ } \\
\text { hts.v71i1.2804 }\end{array}$} \\
\hline \multicolumn{2}{|l|}{$\begin{array}{l}\text { Copyright: } \\
\text { C } 2015 \text {. The Au } \\
\text { Licensee: AOSIS } \\
\text { OpenJournals. T } \\
\text { licensed under } \\
\text { Commons Attrit } \\
\text { License. }\end{array}$} \\
\hline 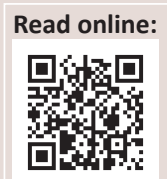 & $\begin{array}{l}\text { Scan this QR } \\
\text { code with your } \\
\text { smart phone or } \\
\text { mobile device } \\
\text { to read online. }\end{array}$ \\
\hline
\end{tabular}

This article presents how Paul, in 1 Thessalonians, executes the process of the formation of the Thessalonian community. Using the sociological concept of symbolic boundaries, it is argued that the resources - (1) the kerygmatic narrative, (2) the local narratives, and (3) the ethical norms - that Paul incorporates into the letter take an essential role to promote the converts to derive a cooperative identity from the community to which they belong and to strengthen the distinction between them and the larger society. By providing internal consensus and external separation, the resources serve to construct and maintain the Thessalonian community that is internally united and externally distinct.

\section{Introduction}

Paul was not just an itinerant preacher. ${ }^{1}$ A corollary of Paul's travels throughout the Mediterranean was his passionate commitment to the formation of Christ-following communities. 1 Thessalonians reflects Paul's commitment, more obviously than in any of his other letters, since the recipients of the letter were facing the challenge of a larger 'pagan' society which could lead to the collapse of the community. In 1 Thessalonians, Paul needed to maintain and reinforce the fledgling community for its well-being.

This article will show how Paul, through 1 Thessalonians, executes the process of the formation of the Thessalonian community. To provide background to the rest of this study, the article will, firstly, introduce the sociological concept of symbolic boundaries. After that, it will focus on three symbolic resources that Paul used in 1 Thessalonians to create boundaries for the Thessalonian community: the kerygmatic narrative, the local narratives, and the ethical norms. This study will argue that these resources played a major role in discriminating between believers as insiders and non-believers as outsiders and in establishing the cooperative identity of the community, thus contributing to Paul's formation of the Thessalonian community.

\section{Symbolic boundaries and community formation}

In recent years, the concept of symbolic boundaries has received much attention in the social sciences. According to Michèle Lamont and Virág Molnár (2002:168), symbolic boundaries are 'conceptual distinctions made by social actors to categorise objects, people, practices, and even time and space'. They are intangible lines that include some people and things whilst excluding others. By widely recognising and accepting the function of symbolic boundaries, both inclusion and exclusion, scholars have applied the concept of symbolic boundaries to various fields of social studies.

As the concept of symbolic boundaries gained analytical prominence across various disciplines, the emergent literature on identity construction and group formation received its due attention. In particular, social psychologists became interested in the concept of social identity of the groups to which individuals belong. According to Henri Tajfel ${ }^{2}$ (1978), social identity is:

... that part of an individual's self-concept which derives from his knowledge of his membership of a social group (or groups) together with the value and emotional significance attached to that membership. (p. 68)

Based on the presupposition that people's identity is profoundly influenced by the groups to which they belong, scholars seek to provide a comprehensive explanation about how identity

1This article is a reworked version of a section of the author's larger research project in Practical Theology with specialisation in Homiletics entitled: 'Paul's preaching for community formation in 1 Thessalonians: An alternative to the new homiletic'. It is being written under the supervision of Cas Wepener and Ernest van Eck at the University of Pretoria.

2.The work of Tajfel and his colleagues developed the theory of social identity, which some scholars have found helpful for understanding the development of the identity of Christ followers. Philip Esler has made the most detailed use of Tajfel's theory in New Testament studies thus far (see Esler 1996; 1998; 2000a). 
is related to '... group membership, group process, and intergroup relations' (Hogg 2006:111).

In contrast to the characterisations of personal identity, the concept of social identity naturally assumes the presence of some commonality amongst the members within a group. Individuals in a same group share a collective identity. In the same group, individuals evaluate themselves in the same way and share a common definition of who they are and what their characteristics are. This similarity intrinsically implies difference. That members of one group are similar in a particular way implies that the members of the group differ from other groups. Therefore, members in the same group recognise their common identity more clearly by comparing and contrasting with people outside of their group. Michael Hogg (2006:115) thus claims the following: 'Group membership is a matter of collective self-construal "we" and "us" versus "them"'. To strengthen the collective identity of a group, it is indispensable to provide the members with a clear description of the similarities within the group and of their differences with other groups.

Boundaries are very critical to the sense of similarity and difference within a group. By clearly drawing a line between 'us' and 'them', boundaries provide the members with a heightened sense of who are similar to us and who are not. Therefore, boundaries function as a medium for the distinction between the in-group and the out-group, as criteria for which members are included and which are excluded. Richard Jenkins (2008:102) writes: 'To define the criteria for membership of any set of object is, at the same time, also to create a boundary, everything beyond which does not belong'. As Penny Edgell, Joseph Gerteis, and Douglas Hartmann (2006) have shown:

\footnotetext{
Symbolic boundaries are effective ... in promoting a sense of solidarity and identity by virtue of imagining an 'other' who does not share the core characteristics imagined to be held by those who are legitimate participants in the moral order; the imagined community must have outsiders as well as insiders. (p. 231)
}

Symbolic boundaries demarcate, distinguish, and exclude 'others'. In so doing, they function to construct a semblance of identity amongst those who fall within the established boundaries of a given formation. The creation of symbolic boundaries for the distinction between insiders and outsiders has a central constitutive role in the production of shared identity within a group.

In addition to serving as criteria for which members of a group to include as insiders and to exclude as outsiders, the drawing of boundaries acts as a means of establishing and maintaining a hierarchical group status between groups. Thomas Gieryn (1983) describes this process of inter group hierarchy creation via the phenomenon in which scientific explanations, rather than metaphysical and religious explanations, became well received. For him, boundary building is '... an ideological style found in scientists' attempts to create a public image for science by contrasting it favourably to non-scientific intellectual or technical activities' (Gieryn 1983:781). Gieryn states that this formation of hierarchical status is the result of successful boundary building accomplished by the scientific community. By drawing boundaries, members of a group position themselves above those with whom they draw distinctions. Boundaries provide the members with a sense of the positive distinctiveness of their group, which successfully convinces them that the in-group is better than the out-group. This in-group conviction then contributes to the creation and maintenance of collective identity and the solidification of the group cohesion.

In sum, symbolic boundaries create not only a common consciousness of a group's own distinctiveness from other groups but also a sense of superiority over other groups. The creation of boundaries can be viewed as a central process to construct common identity and group solidarity. Thus, it is a key to community formation.

\section{Paul's use of the kerygmatic narrative to create boundaries}

Paul incorporated the kerygmatic narrative that he had already preached to the Thessalonians, during his founding ministry, in 1 Thessalonians. The kerygmatic narrative that Paul labels as 'the gospel of God' (1 Thes 2:2, 8-9) and 'the

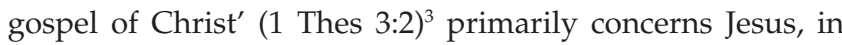
particular, his death or resurrection and his coming. Though he does not tell the full range of the content or the outline of the kerygmatic narrative, Paul's allusions to it are scattered with compact references and brief formulations in the letter. ${ }^{4}$ The kerygmatic narrative in 1 Thessalonians plays a significant role in reminding the converts who belongs to the in-group and who does not, thereby creating a collective identity for the members and delineating a distinction between them and the outside world.

The role of a symbolic boundary is not incidental but intrinsic to the kerygmatic narrative. It is clear that, in the founding ministry, Paul's kerygmatic preaching was the means by which he converted the Thessalonians. Though conversion is a theological matter, it also engages a social dimension people are called out of their previous social world and invited into a new community, sharing a foundation and boundaries. Peter Berger and Thomas Luckmann (1967:157158) refer to this conversion as a process of 're-socialization'. Also, the Thessalonians not only turned away from idols but transformed themselves into a believing community that responded to the kerygmatic narrative from Paul. In the process of re-socialisation, therefore, full reception of the kerygmatic narrative was the prerequisite for entering into the community, and their knowledge of the kerygmatic

3. Both titles of the kerygmatic narrative as used by Paul are very appropriate because God and Christ are 'the two main characters' of the narrative (Mitchell 2003:52).

4.The allusions to the story of Christ's death and resurrection are found in 1 Thessalonians 1:10; $4: 14$ and 5:10, and the allusions to the story of Christ's coming are seen in 1 Thessalonians $2: 19 ; 3: 13 ; 4: 15$ and 5:23. Richard Hays (2002:116) cogently argues that we find in clipped references such as Galatians 3:13-14 and $4: 3-6$ '... the presence and shape of a gospel story to which Paul alludes and appeals'. 
narrative was the essential feature of all members of the community. Thus, Georgia Keightley (1987:155) writes the following: 'Christian identity is immediately attributable to the gospel; as a result of Paul's preaching, the Thessalonians now find themselves to be members of a new society'. Their common group identity was fundamentally shaped by the kerygmatic narrative. At the same time, the people in Thessalonica responded differently to the kerygmatic narrative by Paul and consequently divided into two groups. Some became converts and entered the community whilst others continued to identify themselves primarily in terms of their allegiance to the ancient gods. The reception of the kerygmatic narrative served as an invisible demarcation between the in-group and the outside world. In Paul's initial ministry, therefore, the kerygmatic narrative intrinsically functioned as the symbolic boundary by providing the converts with a common group identity and separating them from the larger society.

It is important to emphasise that Paul, in 1 Thessalonians, retells the kerygmatic narrative, which the Thessalonians already know. Therefore, Paul's main intention for telling the kerygmatic narrative is not to teach something that the listeners do not know but to provide a rhetorical effect for them. Undoubtedly, Paul's repetition of the kerygmatic narrative, which called the community into existence, reminds the converts of the shared foundation of their membership. Communal identity is created and sustained by retelling the founding narrative. James Thompson (2001:145) writes: 'For Paul's original converts, the recitation of the facts of the gospel served as a needed reminder of the conviction that brought a diverse group together as a community'. Paul treats them as a unit with the founding narrative and strengthens their communal identity shaped by the kerygmatic narrative.

Paul's retelling of the kerygmatic narrative also allows the believers to re-experience a sense of distinctiveness as members of the community formed by the narrative and to re-confirm their in-group membership. It is clear that Paul intends to buttress the separation between the in-group and the out-group by retelling the kerygmatic narrative. The distinction is reinforced by the dualistic perspective embedded in the kerygmatic narrative itself. The sharp distinction between the converts who worship the living and true God and others who continue to worship idols has dualistic consequences: The former group is destined to be saved by Jesus at his coming, and the latter group is destined for divine wrath (Wanamaker 2002:135). The repetition of the kerygmatic narrative emphasises and legitimates the dualistic distinction between the Christ-following and pagan communities in Thessalonica.

As far as Paul's technique for telling the kerygmatic narrative goes, he does not tell it in detail but mainly alludes to it. This allusive way of narrating indicates that Paul already had the kerygmatic narrative in common with his listeners and the knowledge of it was shared amongst the listeners.
It presupposes not only a sense of fellowship between Paul and the listeners but also some degree of solidarity and social consensus within the community. Through the use of allusions, Paul appeals to and stimulates the shared knowledge amongst the converts, thereby maintaining the collective identity of the community.

Paul's allusive account of the kerygmatic narrative also creates a distinction between the in-group and the out-group, based on whether or not they understand the allusions. James Dunn (1998) aptly states the following:

It is one's knowledge of the tradition which enables one to recognize the allusions and which thus attests one's membership of the community. Those who do not recognize the allusions thereby demonstrate that they are still outside the community. (p. 652)

Paul's way of telling the kerygmatic narrative separates those who recognise the allusions from those who do not.

In addition to internal cohesion and external separation, Paul's telling of the kerygmatic narrative also serves as a criterion to assure the members' conviction that belonging to the community is superior to not belonging. The kerygmatic narrative confirms the higher status of the members. The main characters of the kerygmatic narrative, shared by the members, are the living and true God and his raised Son, who are qualitatively different from the dead and false idols that the rest of their compatriots worship (1 Thes 1:9-10). N.T. Wright (2009) summarises the shared knowledge shaped by the kerygmatic narrative amongst the Thessalonians:

The creator God was the true God, now made known in Jesus the Messiah, his son, who would come as judge of all things; in this light, pagan deities, their shrines, temples, status and hierarchies, were a bunch of shames, unreal gods who could still enslave people but had no power to save them. (p. 103)

It is evident that their knowledge of relativising other gods strengthens the confidence that their community is better than any other group in the larger society. The kerygmatic narrative's function, justifying their superiority over the rest of Thessalonians, is perhaps at its most obvious in the story of Christ's coming. On 'the day of the Lord' (1 Thes $5: 2$ ), Jesus would come to deliver the believers and to judge the non-believers. Philip Esler (2000b:165) writes: 'The focus in 1 Thessalonians on future events provides an important means of differentiating the positively valued in-group from negatively valued outsiders'. The kerygmatic narrative predicts that the other pagan Thessalonians, who think they are at 'peace and safety' (1 Thes 5:3), will experience inescapable destruction whereas the believers will inherit salvation. The affirmative denouement of the kerygmatic narrative, of which Paul reminds his audience, convinces the converts that their community is distinctly superior to the rest of the Thessalonians who are destined to the negative ending. 


\section{Paul's use of the local narratives to create boundaries}

In addition to the kerygmatic narrative, Paul also weaves local narratives into 1 Thessalonians, which embraces stories of Paul with his fellow missionaries and of the Thessalonian believers. The central focus in Paul's way of telling local narratives facilitates the converts to derive a common identity from the community to which they belong and to differentiate their community from the outside world.

The function of the symbolic boundary can be found in Paul's telling of his story concerning his work amongst the Thessalonians (1 Thes 2:1-2; 2:5-12). Paul assumes that the listeners are familiar with his story of the founding visit, and thus, he primarily tells the story based on the recollection of the believers. This is clearly shown in Paul's repeated use of the phrases to appeal to the memory of the Thessalonians: 'you know' (oif $\delta \alpha \tau \varepsilon ; 1$ Thes 2:1; 2:2; 2:5; 2:11), 'you remember' (1 Thes 2:9), ${ }^{5}$ and 'you are witnesses' (1 Thes 2:10). In Paul's story concerning his stay in Thessalonica, his use of the formula's 'recall motif' is frequent (Collins 1993:11). Paul's appeal to the recollection provides the sense of an intimate relationship between him and the converts by recognising and reiterating the shared memory. Perhaps most importantly for the topic of this article, Paul's reminders of the collective memory amongst the converts create and support the communal identity of the community. The common identity of a group is grounded in the shared memory of the group. Group memory is the means by which a group identifies with its common past. ${ }^{6}$ Georgia Keightley $(1987)^{7}$ notes:

Recollections associated with the period of origins as well as those subsequently recognized as having significance for the shared life are particular to it and make the community what it is. In truth, procession of a select body of memory serves to distinguish one community from another. (p. 152)

Collective memory is certainly essential to the articulation of the corporate identity of a community. The same is true of the Thessalonian community. Paul constantly recalls the converts' collective memory in his way of telling his story so that they can construct and strengthen their collective identity.

It should be noted that Paul reminds the converts about his story to give them an example to imitate. ${ }^{8}$ Paul invites the converts to remember his own witness, in particular the manner in which he lived and worked, and to follow 5.According to Wanamaker (1990:102), the reason why Paul use the term instead of
'you know' might be related to 'stylistic variation'.

6.Sociologist, Maurice Halbwachs was a pioneer in a new approach to social or collective memory. He argues that memory is socially determined; it is a social and collective phenomenon: 'It is in society that people normally acquire their memories. It is also in society that they recall, recognize and localize their memories' (Halbwachs 1992:38).

7.In the article, Keightley applies Halbwachs's theory of the collective memory to her analysis of 1 Thessalonians. For a succint but encompassing explanation of the social scientific concept of social memory, see Van Eck (2011:201-205).

8.This argument is based on the assumption that Paul's autobiographical sections are parenetic rather than apologetic in nature (see Lyons 1995:207-209). the pattern of his own story. Abraham Malherbe (1987:52) writes that '... Paul's method of shaping a community was to gather converts around himself and by his own behavior to demonstrate what he taught'. It is natural that imitation is an effective process to build up a new community like the Thessalonian church with its new converts. In addition, that the imitation of Paul's story is fundamental to his construction of communal identity within the community should not be underestimated. Paul's story functions as an 'in-group prototype', which can be defined as the shared cognitive representation of the ideal group member (Roitto 2008:107). Within the community, Paul's story is the exemplar that prescribes to the converts who they are and how they should behave. Therefore, the account of Paul's story manifests the consensus of the community, and the listeners can ground their common identity by remembering and imitating his story.

Whilst Paul's telling his story about the founding ministry strengthens cohesion amongst those who know and imitate his story, the story also provides the listeners with a strong sense of distinction from those who are not in the community. Those who are not in the community do not know Paul's story and do not imitate it. Paul's story functions as the distinction between the in-group and the out-group. Remembering and imitating Paul's story highlight the symbolic distinction between the two groups.

Communal identity is also strengthened by Paul's telling of the conversion story accompanied by the kerygmatic narrative (1 Thes 1:9-10) since the converts reacted to the kerygmatic narrative in the same way, that is, it is their collective story. Hearing and remembering their collective story together construct a collective identity amongst the listeners. Their collective identity is reinforced by remembering their collective story. In particular, the Thessalonians' suffering story is fundamental to Paul's construction of collective identity for those in the community. Paul tells the story about their suffering situation (1 Thes $1: 6 ; 2: 14 ; 3: 3)$. In terms of suffering, Paul states that they became imitators of both Paul and the Lord (1 Thes 1:6; 2:13-14). 'For Paul' as Burton Mack (1995:184) notes, '... Christian existence was understood as an imitation of the sufferings and sacrificial death of Christ'. Their suffering story not only functions to establish a connection between Christ, Paul and the community, but it also maintains their cooperative identity - all shared in persecution. Persecution marks those who are in the community. It is obvious that their suffering story also identifies those who are not in the community. The outsiders do not follow Christ and thus do not suffer. They even oppress the Christ-following community. Paul's telling of their suffering strengthens the boundary between 'us' and 'them.'

\section{Paul's use of the ethical norms to create boundaries}

When Paul states his ethical instructions to the Thessalonians, he mainly focuses on sexual matters (1 Thes 4:3-8) and 
brotherly love (1 Thes 4:9-12). It is necessary to emphasise that the purpose of Paul's exhortations is more than to teach the converts ethical norms. This is because Paul has already instructed them concerning the norms during his founding mission ( 1 Thes 4:2,9), and even they have abided by the norms of brotherly love (1 Thes 4:9-10). Paul's ethical norms have social functions. The moral discipline of the converts could operate as the symbolic boundary for the community and distinguish the converts from the outside world.

Paul's prescription for sexual practice is not only for the advancement of virtue amongst the converts but also for the task of community formation by maintaining the collective identity of the believing community and separating it from the pagan society. The corporate identity formed by the attitudes and behaviour in accordance with Paul's sexual norms is qualified as holiness. The concept of holiness has never been found in pagan literature, and no Greco-Roman moralist has been concerned with holy living (Fee 2009:144145). Paul's attention to holiness must come from his Jewish background such as the Holiness Code in Leviticus 17-26. Just as God called Israel to be holy as God is holy, Paul reminds the converts that God 'called' them not to impurity but 'in holiness' (1 Thes 4:7). In Jeffery Weima's (1996:103-104) argument, Paul suggests the gentile converts in Thessalonica to be 'the renewed Israel' by applying to them the concept of holiness that has been the exclusive privilege of Israel. Though it could not be affirmed whether the gentile converts unfamiliar with Jewish tradition fully understood Paul's intention, connecting them to Israel's identity, the shared lifestyle that conformed to Paul's exhortations on sexual morality must have cultivated the communal identity of the community: holiness.

It may be supposed that Paul's sexual norms would enhance the social stability and internal cohesion of the community. Whilst some might advocate that sexual activity should be located only in the private sphere, Paul believes that it ought to be practiced by social relationships. Paul prescribes practicing sexual norms in a way that is not only holy but also 'honourable' (1 Thes 4:4). Honour in the GrecoRoman society related to high value acquired through social relationships. Paul's use of terms with connotations with business ethics also implies that his sexual norms have a social dimension. Lone Fatum (1997:190) thus concludes that, in the sexual instructions, Paul 'addresses the sociosexual activities'. Therefore, Paul believes that dishonourable sexual activities should be prohibited since they would increase tension amongst the converts and threaten the harmony of the community, which could consequently lead to the collapse of the community. Jouette Bassler (1994) writes:

The emphasis here on holiness/sanctification is clear, yet when Paul defines more precisely what this means, it also becomes clear that actions that lead to holiness also lead to peace. (p. 83)

Paul's sexual norms also involve attributes of inner harmony in the community.
The other function of Paul's exhortations on sexual conduct is the emphasis on separation. Paul's sexual norms play a role in the distinction between those inside and those outside of the community. From the Jewish perspective, holiness, the ideal of Paul's sexual morality, is associated with the concept of separation: 'You are to be holy to me because I, the LORD, am holy, and I have set you apart from the nations to be my own' (Lv 20:26). Holiness is the boundary maker that separates God's people from the people around them. Given the pagan culture where sexual immorality was pervasive, ${ }^{9}$ Paul undoubtedly expects this boundary maker in matters of sexual conduct to separate the converts from the pagan society to which they previously belonged. By insisting that the converts practice sexual behaviour in holiness, Paul draws a symbolic boundary around the community.

The distinction created by the moral boundary is also clearly found in Paul's use of terms of reference to represent two opposing groups, each with its own distinctive features and conduct. Regarding the group to which the converts belong, there is the intimate relationship amongst 'brothers' (1 Thes 4:1, 6) who have been 'called' by God (1 Thes 4:7). Their lifestyle is qualified as 'holiness' ( 1 Thes $4: 3,7,8)$. In contrast, the divergent group is defined by 'sexual immorality' (1 Thes 4:3), 'passionate lust' ( 1 Thes 4:5), being 'impure' (1 Thes 4:7), and as 'the heathens who do not know God' (1 Thes 4:5). Paul's contrasting way of narrating serves to mark the difference between the two groups and draws a clear line of demarcation between them. Craig de Vos (1999:173), therefore, writes the following: 'This in itself creates, or at least encourages, a dichotomy between those inside and outside the Christian community.'

It is necessary to note that Paul's contrasting language positive language for the in-group and negative language for the out-group - indicates his attempt to install the superiority of the in-group within the community. It is no wonder that there are qualitative differences between the in-group lifestyle, defined as holiness, and the out-group, defined as sexual immorality. For this reason, Philip Esler (2000b) makes the following claim:

Paul's insistence on behavioural norms falls within the larger purpose of recommending to the Thessalonian Christ-followers a positive identity. In other words, Paul may want to tell them how they should behave, but only in the course of installing in their consciousness the larger and more important reality of who they are. (p. 171)

Their holy lifestyle provides them with a sense of righteousness, especially in the eyes of God who '... will punish men for all such sins' (1 Thes 4:6). God's favour would create a sense of superiority over those '... who do not know God' (1 Thes 4:5).

9.Weima (1996:104-105). Wayne Meeks (1986:128) writes: "The specific mora expectations that Paul expresses, of the sort that one could state as moral rules, are hardly different from those widely accepted as 'decent' in Greco-Roman society'. 
Paul's ethical norms of brotherly love also have a social function, namely as the symbolic boundary to create the collective identity of the community and to develop group solidarity. With the norms of brotherly love, Paul intends to shape the believing community into a surrogate family group. This intent can be inferred from his usage of $\varphi 1 \lambda \alpha \delta \varepsilon \lambda \varphi \varphi^{\prime} \alpha$. Prior to Paul's usage of it, the word was used almost exclusively for the love of biological siblings. The term is also rarely used in the New Testament. ${ }^{10}$ In fact, Paul uses $\varphi \imath \lambda \alpha \delta \varepsilon \lambda \varphi \varphi^{\prime} \alpha$ only twice, including in this case. ${ }^{11}$ Thus, one might think that there is no apparent explanation for Paul's usage of the term instead of $\dot{\alpha} \gamma \alpha \dot{\pi} \eta$, which is normally used in the New Testament. ${ }^{12}$ In this context, nevertheless, Paul's metaphorical application of $\varphi \imath \lambda \alpha \delta \varepsilon \lambda \varphi i^{\alpha} \alpha$ shows that he intended to construct the believing community as a surrogate kinship group by encouraging a genuine feeling of kinship amongst the listeners who had no basis for a reciprocal relationship before entering the community. ${ }^{13}$

Paul, however, recognises that the kinship community in Thessalonica cannot be constructed by the metaphorical use of family language only. For its formation, each member, as a brother, is evidently expected to have and perform habits and ways of living in accordance with the kinship community. Members are required to act as brothers in the same family. In this regard, David Horrell (2005:113) thus labels Paul's ethics as 'role-ethics', a set of expectations about how behaviour should be shaped according to a role-designation as brothers. Paul advises the Thessalonian converts about how they can behave as siblings in the new family group - the role of siblings in brotherly love. The awareness about the role of brothers and the attitudes and behaviour governed by the role provide the converts with an unambiguous brotherhood to which they belong in the same family. Clearly, the sibling relationships construct the kinship community.

The apparent awareness of brotherhood and its lifestyle necessarily accompanies the awareness of those who are not truly brothers. By Paul's norms of brotherly love, the line of separation is drawn between the siblings and those who do not belong, the non-siblings. The social function of Paul's ethical norms of brotherly love is twofold: internal cohesion and external separation. Raymond Collins (1984) appropriately encapsulates this idea:

For Paul to write of the church of the Thessalonians as a brotherhood is to say something about that community $a b$ intra and ad extra. Brotherhood speaks of togetherness and apartness. The recognition of their existence as a specific religious brotherhood marks a distinctive stage in the ecclesial self-awareness of the Thessalonians ... The recognition of brotherhood is a recognition of distinctness, yet the recognition is also a recognition of togetherness. Ab intra the description of a

10. Hebrews 13:1; 1 Peter 1:22; 2 Peter 1:7

11.The other case is found in Romans 12:10.

12.Similarly, see Betz (1978:232).

13.Although Paul, by using kinship language, usually depicts his believing communities as family groups, this strategy is particularly conspicuous in 1 Thessalonians. community as a brotherhood draws attention to the bonds that link the matters together. (p. 296)

It is necessary to point out that the external dynamic of Paul's norms of love is not restricted to the separation from non-siblings. The ethical norms are involved in the concern to '... win the respect of outsiders' (1 Thes 4:12). This concern shows that Paul assumes that the family group is superior to any other group, and the honour of the family is thus to be maintained in the eyes of those outside of the community. By the exhortation to honourable conduct suitable for the family honour, Paul shares a sense of superiority with the listeners and reinforces the hierarchical status of the community. Paul's norms of brotherly love embody the honour of the family, and its superiority, in external relationships.

\section{Conclusion}

Paul proficiently intertwines the kerygmatic narrative, the local narratives, and the ethical norms in 1 Thessalonians. Paul's aim to incorporate these resources into his letter is not primarily to convey information unfamiliar to the listeners since he indicates that he had already taught them. Also, they already knew his teachings, and they even already lived his teachings in a variety of ways. Rather, his chief goal is to enhance and to maintain the community facing a serious challenge that could destroy it. Paul's primary goal is not informative, it is formative. In other words, the kerygmatic narrative, the local narratives, and the ethical norms take on a social function in 1 Thessalonians.

The sociological concept of symbolic boundaries is probably the best way to explain the social function of these resources in the letter. Serving as criteria through which members of a group include insiders and exclude outsiders, the symbolic boundaries provide the members with a collective identity and distinguish them from other groups with a sense of distinctiveness or superiority. Boundary building is absolutely indispensable to the formation of a community. To create and maintain boundaries, Paul inserts the kerygmatic narrative, the local narratives, and ethical norms. Functioning as symbolic boundaries, these resources in 1 Thessalonians take an important role to promote the converts to derive a cooperative identity from the community to which they belong and strengthen the distinction between them and the larger society. By providing the converts with internal consensus and external separation, Paul's use of the kerygma, the local narratives, and ethical norms in 1 Thessalonians serves to construct and maintain the Christfollowing community that is internally united and externally distinct.

\section{Acknowledgements Competing interests}

The authors declare that they have no financial or personal relationship(s) that may have inappropriately influenced them in writing this article. 


\section{Authors' contributions}

K.C. (University of Pretoria) was the PhD student. E.v.E. (University of Pretoria) and C.W. (University of Pretoria) acted as supervisors.

\section{References}

Bassler, J.M., 1994, 'Peace in all ways: Theology in the Thessalonian Letters. A response to R. Jewett, E. Krentz, and E. Richard', in Pauline Theology, vol. 1, pp. 71-85, Fortress Press, Minneapolis, MN.

Berger, P.L. \& Luckmann, T., 1967, The social construction of reality: A treatise in the sociology of knowledge, Anchor Books, New York.

Betz, H.D., 1978, 'De Fraterno Amore', in H.D. Betz (ed.), Plutarch's ethical writings and early Christian literature, pp. 231-263, Brill, Leiden.

Collins, R.F., 1984, Studies on the first letter to the Thessalonians, University Press, Leuven.

Collins, R.F., 1993, The birth of the New Testament: The origin and development of the first Christian generation, Crossroad, New York.

De Vos, C., 1999, Church and community conflicts: The relationships of the Thessalonian, Corinthian, and Philippian churches with their wider civic communities, Scholars Press, Atlanta.

Dunn, J.D.G., 1998, The theology of Paul the apostle, W.B. Eerdmans Publishers, Grand Rapids.

Edgell, P., Gerteis, J. \& Hartmann, D., 2006, 'Atheists as "other": Moral boundaries and cultural membership in American society', American Sociological Review 71(2), 211-234. http://dx.doi.org/10.1177/000312240607100203

Esler, P.F., 1996, 'Group boundaries and intergroup conflict in Galatians: A new reading of Galatians 5:13-6:10', in M.G. Brett (ed.), Ethnicity and the Bible, pp. 215-240, E.J. Brill, Leiden.

Esler, P.F., 1998, Galatians, Routledge, London.

Esler, P.F., 2000a, 'Jesus and the reduction of intergroup conflict: The parable of the Good Samaritan Jesus and the reduction of intergroup in the light of social identity theory', Biblical Interpretation 8(4), 325-357. http://dx.doi. org/10.1163/156851500750118953

Esler, P.F., 2000b, 'Keeping it in the family: Culture, kinship and identity in 1 Thessalonians and Galatians', in J.W. van Henten \& A. Brenner (eds.), Families and family relations as represented in Early Judaisms and early Christianities: Texts and family relations as represented in Eartions, pp. 145-184, Deo, Leiden.
fiction

Fatum, L., 1997, 'Brotherhood in Christ: A gender hermeneutical reading of 1 Thessalonians', in H. Moxnes (ed.), Constructing early Christian families: Family as social reality and metaphor, pp. 183-215, Routledge, New York.

Fee, G.D., 2009, The first and second letters to the Thessalonians, W.B. Eerdmans Publishers, Grand Rapids.
Gieryn, T.F., 1983, 'Boundary-work and the demarcation of science from non-science: Strains and interests in professional ideologies of scientists', American Sociological Review 48(6), 781-795. http://dx.doi.org/10.2307/2095325

Halbwachs, M., 1992, On collective memory, University of Chicago Press, Chicago.

Hays, R., 2002, The faith of Jesus Christ: The narrative substructure of Galatians 3:1-4:11 W.B. Eerdmans Publishers, Grand Rapids.

Hogg, M.A., 2006, 'Social identity theory', in P.J. Burke (ed.), Contemporary social psychological theories, pp. 111-136, Stanford Social Sciences, Stanford.

Horrell, D.G., 2005, Solidarity and difference: A contemporary reading of Paul's ethics, T \& T Clark International, New York.

Jenkins, R., 2008, Social identity, Routledge, London.

Keightley, G.M., 1987, 'The church's memory of Jesus: A social science analysis of 1 Thessalonians', Biblical Theology Bulletin 17(4), 149-156.

Lamont, M. \& Molnár, V., 2002, 'The study of boundaries in the social sciences', Annual Review of Sociology 28, 167-195. http://dx.doi.org/10.1146/annurev. soc.28.110601.141107

Lyons, G., 1995, 'Modeling the holiness ethos: A study based on First Thessalonians', Wesleyan Theological Journal 30(1), 187-211.

Mack, B.L., 1995, Who wrote the New Testament?: The making of the Christian myth, Harper, San Francisco.

Malherbe, A.J., 1987, Paul and the Thessalonians: The philosophic tradition of pastoral care, Fortress Press, Philadelphia.

Meeks, W.A., 1986, The moral world of the first Christians, Westminster Press, Philadelphia.

Mitchell, M.M., 2003, '1 and 2 Thessalonians', in J.D.G. Dunn (ed.), The Cambridge companion to St. Paul, pp. 51-63, Cambridge University Press, Cambridge.

Roitto, R., 2008, 'Behaving like a Christ-believer: A cognitive perspective on identity and behavor norms in the early Christ-movement', in B. Holm (ed.), Exploring early Christian identity, pp. 93-114, Mohr Siebeck, Tübingen.

Tajfel, H., 1978, 'Social categorization, social identity and social comparison', in H. Tajfel (ed.), Differentiation between social groups: Studies in the social psychology of intergroup relations, pp. 61-76, Academic Press, London.

Thompson, J., 2001, Preaching like Paul: Homiletical wisdom for today, Westminster John Knox Press, Louisville.

Van Eck, E., 2011, 'Social memory and identity: Luke 19:12b-24 and 27', Biblical Theology Bulletin 41(4), 201-212. http://dx.doi.org/10.1177/0146107911423081

Wanamaker, C.A., 1990, The epistles to the Thessalonians: A commentary on the Greek text, W.B. Eerdmans Publishers, Grand Rapids.

Wanamaker, C.A., 2002, 'Apocalyptic discourse, paraenesis and identity maintenance in 1 Thessalonians', Neotestamentica 36(1), 131-145.

Weima, J.A.D., 1996, 'How you must walk to please God: Holiness and discipleship in 1 Thessalonians', in R.N. Longenecker (ed.), Patterns of discipleship in the New Testament, pp. 98-119, W.B. Eerdmans Publishers, Grand Rapids.

Wright, N.T., 2009, Paul in fresh perspective, Fortress Press, Minneapolis. 